\title{
The Last Glacial-Interglacial Transition
}

\author{
Department of Physical Geography, Faculty of Geosciences, Utrecht University, Heidelberglaan 2, NL 3508 TC Utrecht, The Netherlands. \\ E-mail:w.hoek@geo.uu.nl
}

\begin{abstract}
The Last Glacial-Interglacial Transition is one of the most intensively studied periods in Earth History. The rapid climate and environmental changes that occurred during the transition can be used to test ideas about the functioning of our climate system. The stratigraphy of this period has been thoroughly investigated and, in particular, the recently proposed event stratigraphy for the Last Glacial-Interglacial Transition based on the Greenland ice core records serves as a tool for synchronisation of records from the ice, marine and terrestrial environment. The causes behind the rapid climate changes are most likely to have been changes in ocean circulation, partly triggered by ice-melting during deglaciation. While the picture for the North Atlantic region is becoming more and more clear, complex patterns of change over the globe remain to be studied. The functioning of the complex feed-back mechanisms requires an interdisciplinary approach between geoscientists from different disciplines.
\end{abstract}

\section{Introduction}

The Last Glacial-Interglacial Transition (LGIT), often referred to as Weichselian Lateglacial or Last Termination (ca 13,000-10,000 ${ }^{14} \mathrm{C}$ yrs BP), marks the transition from the cold Weichselian Glacial to the warm Holocene. The LGIT is classically sub-divided into a series of cold stadials such as the Younger Dryas Stadial (named after the occurrence of the characteristic arctic-alpine plant species Dryas octopetala) separated by warm interstadials named after the type localities Bølling and Allerød in Denmark. This climatostratigraphic sub-division has been extensively used in NW-Europe, usually in a chronostratigraphic sense, and is still widely employed globally.

The rapid climate changes that occurred during the LGIT, have stimulated the palaeoclimate research community to study this period intensively. This is not only because it provides the opportunity to investigate the nature of the climate changes in high-resolution, but also to test hypotheses on the mechanisms behind the abrupt changes using palaeoclimate modelling. This makes the LGIT one of the most thoroughly investigated of all geological episodes. As a result, the stratigraphy of this time period is relatively well developed.

\section{History}

In 1901, Hartz and Milthers used deposits in a clay-pit near Allerød (Denmark) to demonstrate that a climatic warming occurred during the Lateglacial. Between two clay layers containing leaves of mountain avens (Dryas octopetala) and fossils of reindeer (Rangifer tarandus), an organic layer with birch remains (Betula spp.) and fossils of the European elk (Alces alces) was present, indicating a change from tundra to a more forested environment followed by a return to tundra. Based on palynology, Jessen (1935) was able to define three successive pollen zones: Early Dryas (I), Allerød (II), and Late Dryas (III). This subdivision was further refined by Iversen (1942), who added another interstadial phase that supposedly occurred before the Allerød and was based on evidence from the site at B $\varnothing$ lling $\mathrm{S} \varnothing$ (Denmark).

The palynological sub-division of the Weichselian Late Glacial established by Jessen (1935) and Iversen (1942), was introduced into The Netherlands by van der Hammen (1949), who recognized the Bølling and Allerød oscillations, separated by the colder Dryas stadials in the lake deposits of Hijkermeer. The interstadial deposits were characterised by a higher content of organics in comparison with the stadial deposits. Van der Hammen (1951) went on to demonstrate a similar vegetation development at different locations in The Netherlands and nearby areas. In Central Europe, the scheme described by Firbas (1954) has been more widely used. His definition, particularly of the Oldest Dryas which is not so characteristic in NW Europe, has continued to be used in the Alpine region. Since then, hundreds of pollen diagrams from Late Glacial deposits have been constructed using the subdivisions suggested by van der Hammen and Firbas.

\section{Chronostratigraphy of the Last Glacial Interglacial Transition}

With the introduction of the radiocarbon dating method, biostratigraphic correlation became less important and pollen diagrams were considered more frequently in a chronological context. Moreover, the terminology that was originally developed for biostratigraphical zones (Bølling, Allerød, etc.) has been used throughout northern and western Europe in a chronostratigraphic sense (Mangerud et al., 1974). Since then, the terms Bølling and Allerød have been connected worldwide to the time period between 13,000 and $11,000{ }^{14} \mathrm{C}$ yr BP as defined by Mangerud et al. (1974), while the Younger Dryas chronozone falls between 11,000 and $10,000{ }^{14} \mathrm{C}$ yr BP (Table 1). This chronological subdivision was initially based on the radiocarbon dated biostratigraphic zone boundaries from southern Scandinavia, and predated important later advances in radiocarbon dating such as AMS and radiocarbon calibration.

\section{Bio- and chronostratigraphy}

Boundaries of similar biostratigraphical zones defined in different regions are in most cases diachronous due to differences in biological response to changes in climate. This means that the biostratigraphic zones as defined in Scandinavia are difficult to apply outside this geographical region. Terms such as Lateglacial Interstadial or Windermere Interstadial have been used for the Bølling-Allerød interstadial complex in Britain, where it is often difficult to recognize stadial conditions between the two separate interstadial phases. Furthermore, there are problems relating to biostratigraphic 
Table 1 Chronostratigraphy of the Late Weichselian based on the classical Stratigraphy of Norden after Mangerud et al.

\begin{tabular}{ll}
\hline chronozone & ${ }^{14} \mathbf{C}$ age BP \\
\hline FLANDRIAN (HOLOCENE) & \\
\hline Younger Dryas & 10,000 \\
\hline Allerød & 11,000 \\
\hline Older Dryas & 11,800 \\
Bølling & 12,000 \\
MIDDLE WEICHSELIAN & 13,000 \\
\hline
\end{tabular}

definition. In Germany, an additional interstadial called Meiendorf has often been recognized, which correlates to the Bølling interstadial in the surrounding countries. But in this particular case, the term Bölling is used for what is effectively the first part of the Allerød interstadial in the surrounding countries, leading to considerable confusion. This apparent discrepancy between the definition of $\mathrm{B} \varnothing$ lling and Allerød is mainly the result of a difference of opinion over correlation by Iversen (1942) with the section at Bølling Sø (de Klerk, 2004). These examples highlight some of the problems of transferring a biostratigraphic zonation scheme from one region to another.

The chronostratigraphic approach, originally developed for Scandinavia, can be compared to that in other areas of northwest Europe, and again differences emerge. In The Netherlands, for example, where there are a number of ${ }^{14} \mathrm{C}$-dated Lateglacial pollen diagrams, the onset of the Lateglacial Interstadial falls between 12,500 and $12,450{ }^{14} \mathrm{C}$ yrs BP (Hoek, 2001). This is considerably later than the start of classically defined Bølling in Scandinavia (Table 1). The start and end of the Younger Dryas Stadial in the Netherlands, however, have been dated at 10,950 and $10,150{ }^{14} \mathrm{C}$ yrs $\mathrm{BP}$, respectively, and are more in accordance with the chronostratigraphic boundaries defined by Mangerud et al. (1974).

\section{Event stratigraphy}

As mentioned above, the application of biostratigraphic terminology to records from different regions and different spheres often cause correlation problems.

In an attempt to resolve some of these difficulties, the INTIMATE group of the INQUA Palaeoclimate Commission developed an Event Stratigraphy for the North Atlantic region, based on the Greenland ice-core record (Björck et al., 1998; Walker et al., 1999). This scheme defines a series of stadials and interstadials for the period 23,000 to 11,500 ice-core years BP, based on marked oxygen isotope variations in the GRIP ice core. Greenland Interstadial 1 (GI1), which is broadly correlative with the Lateglacial or BøllingAllerød Interstadial, was subdivided into three warmer episodes GI1a, GI-1c and GI-1e with intervening colder periods GI-1b and GI$1 \mathrm{~d}$.

It is important to stress that the INTIMATE Event Stratigraphy scheme was not proposed as the replacement for the existing regional stratigraphies, but rather as a standard against which to compare those stratigraphic schemes. Furthermore, it was intended that the Event Stratigraphy should serve as a basis for establishing the synchroneity (or asynchroneity) of comparable events or sequences of events throughout the North Atlantic region (Lowe et al., 2001).

The event stratigraphic scheme has recently been revised (Lowe et al., 2008) based upon the new Greenland Ice core record from NorthGRIP (NGRIP) and the associated Greenland Ice Core Chronology 2005 (GICC05) (Rasmussen et al., 2006). The ice-core based event stratigraphy has the advantage of being based on a con-
Table 2 Event stratigraphy for the Last Glacial-Interglacial Transition based on the NGRIP oxygen isotope stratigraphy presented on the GICC05 timescale (Rasmussen et al., 2006): age b2k is before $2000 A D$ with the maximum counting error (MCE) and conversion to cal BP (before 1950).

\begin{tabular}{lccc}
\hline & age b2k & MCE & cal BP \\
\hline Holocene & 11,703 & 99 & 11,653 \\
\hline GS-1 & & \\
\hline GI-1a & 12,896 & 138 & 12,846 \\
\hline GI-1b & 13,099 & 143 & 13,049 \\
\hline GI-1c & 13,311 & 149 & 13,261 \\
GI-1d & 13,954 & 165 & 13,904 \\
\hline GI-1e & 14,075 & 169 & 14,025 \\
- GS-2 & 14,692 & 186 & 14,642 \\
\hline
\end{tabular}

tinuous and annually resolved palaeoclimate archive, which provides an unprecedented level of precision and accuracy for determining the timing and duration of climate events during the LGIT (see further Lowe et al., 2008).

The revised INTIMATE event stratigraphy for the LGIT in the North Atlantic region is presented in Table 2. The ages for the event boundaries are derived from the GICC05 timescale (Rasmussen et al., 2006) in years b2k (= before 2000 AD). Note that this ice-corebased time-scale is different from the calibrated ${ }^{14} \mathrm{C}$-timescale given in cal BP (=before $1950 \mathrm{AD}$ ). In effect, there is an offset of 50 years between the two timescales which must be taken into account when comparing ice-core years to ${ }^{14} \mathrm{C}$-dated events.

An additional basis for correlation in the North Atlantic region during the LGIT is provided by tephrochronology. This time period in geological history is marked by the frequent occurrence of volcanic eruptions, possibly related to the glacio-isostatic compensation since the last deglaciation, and both visible and microtephras form valuable time-parallel marked horizons in marine and terrestrial sediments, and also in the ice-core record (Turney et al., 2004; Alloway et al., 2007; Lowe et al., 2008).

\section{Discussion: climate changes during the Last Glacial-Interglacial Transition}

Although lithological and botanical evidence shows that marked environmental changes occurred during the Lateglacial, it is often difficult to relate these signals directly to climate. The AP (Arboreal Pollen) percentage was long considered as a direct temperature proxy. Based on the palynological records, in which the AP percentage increased during the course of the Bølling-Allerød Interstadial, it was concluded that the warmest part of the Lateglacial occurred towards the end of the Allerød interstadial, just before the onset of the Younger Dryas Stadial. Evidence from fossil beetles (Coleoptera), however, suggested a different scenario, with the warmest phase occurring early in the Lateglacial (Coope, 1970; Coope et al., 1971). This interpretation was subsequently confirmed by data from the Greenland ice-core record, notably GRIP (Johnsen et al., 1992) and GISP2 (Grootes et al., 1993). Hence, the long-standing interpretation of Lateglacial climate and vegetational development appeared to be in error: the warmest phase did not occur during the Allerød, but rather during the Bølling when the extent of arboreal vegetation was limited. However, the timing of the changes in vegetation composition appears to be synchronous with the climate changes recorded in the oxygen isotope records in both ice-cores and calcareous lake deposits, for example in the Swiss Alps (Lotter et al., 1992) and in Central North America (Yu and Eicher, 1998). This points to a common temperature trend during the LGIT throughout the Atlantic region. Ammann et al. (2000), and Birks et al. (2000) found that at the beginning and end of the Younger Dryas in Ger- 


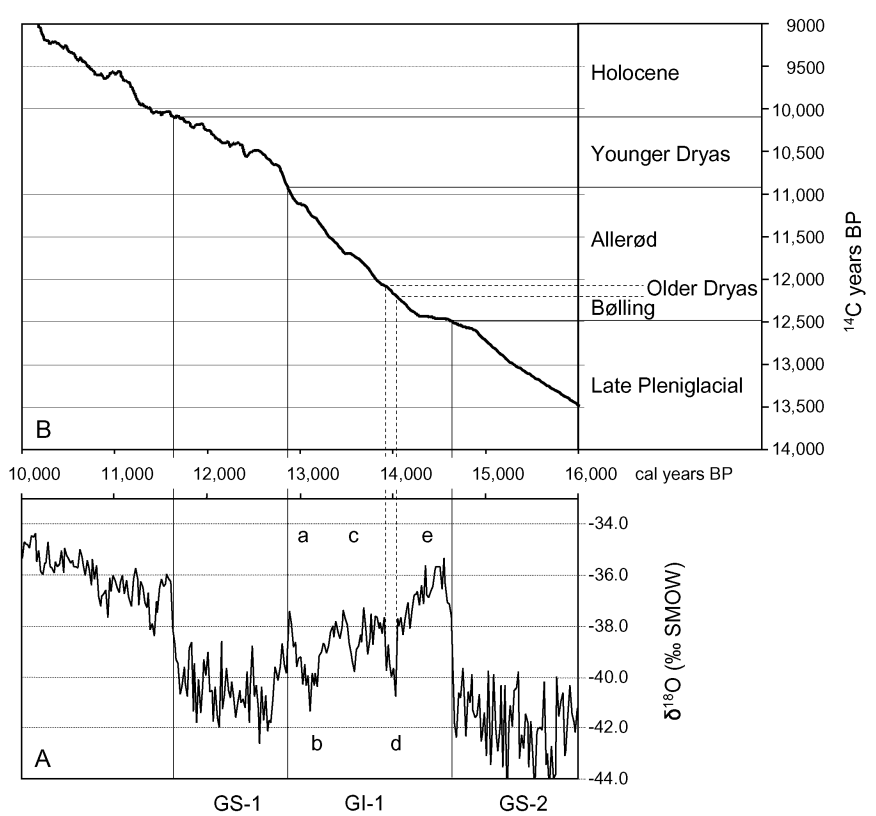

Figure 1 Correlation between the event stratigraphy for the Last Glacial-Interglacial Transition (A) after Lowe et al. (2008) plotted on a time scale in ice-layer counts $B P(=1950 \mathrm{AD}$ or b2k minus 50 years) and the classic Lateglacial stratigraphy of $N W$ Europe $(B)$ plotted on a ${ }^{14} \mathrm{C}$ time scale. The correlation has been made using the INTCAL04 calibration curve (Reimer et al., 2004).

many, Switzerland, and Norway, respectively, hardly any or no biotic lags occurred. This can also be deduced from figure 1, where the Greenland isotope events are compared with the classic Lateglacial stratigraphy for NW Europe. In this comparison, the ice core years (plotted in cal BP) are transferred to ${ }^{14} \mathrm{C}$ years BP using the INTCAL04 calibration dataset (Reimer et al., 2004). There is a remarkable similarity between the major zone boundaries and the transitions between GI-1, GS-1 and the Holocene, corresponding with, respectively, $12,500,11,900$, and $10,150{ }^{14} \mathrm{C}$ yrs $\mathrm{BP}$ as ${ }^{14} \mathrm{C}$ dated in The Netherlands (see Figure 1 and above).

The causes behind the abrupt climate changes are still not completely resolved, although it is obvious that the changes in ocean circulation played a crucial role (Broecker, 1998). Furthermore, the interaction of the cryosphere and the ocean, in particularly the Atlantic (Bond et al., 1992), is believed to have been the major cause behind the rapid climate changes during the LGIT. The Younger Dryas (GS-1) was most likely caused by changes in Thermohaline Circulation in the North Atlantic as a result of fresh water forcing, while the start of the Holocene seems approximately to coincide with the onset of a ${ }^{14} \mathrm{C}$ plateau, implying an increased global ocean ventilation rate (Hughen et al., 2004; Björck, 2006).

The findings that warmings during glacial time in Antarctic ice cores roughly coincide with cold periods over the Greenland Summit, and vice versa, led to the hypothesis of a bi-polar seesaw climate pattern (Broecker, 1998). Meltwater Pulse 1a (a major influx into the world's oceans of meltwaters from wasting ice sheets) seems to coincide with the onset of GI-1 warming in the N-Atlantic at around 14.7 $\mathrm{ka}$, and probably originated from the Antarctic Ice (Weaver et al., 2003). The occurrence of the Heinrich 1 event (massive iceberg discharge into the North Atlantic) at around $17.5 \mathrm{ka}$ seemed to be the major cause in large changes in the meridional overturning registered in marine cores. This coincides with the onset of deglacial warming in the Antarctic, which has been referred to as the 'Mystery Interval' (Denton et al., 2006).

As the term 'Mystery Interval' indicates, there are substantial issues that remain to be solved. Clear differences can be observed in the registration of the climate signal between the southern and northern Hemispheres (see Figure 2). The Antarctic Cold Reversal (ACR) began more than 1000 years before the onset of the Younger Dryas

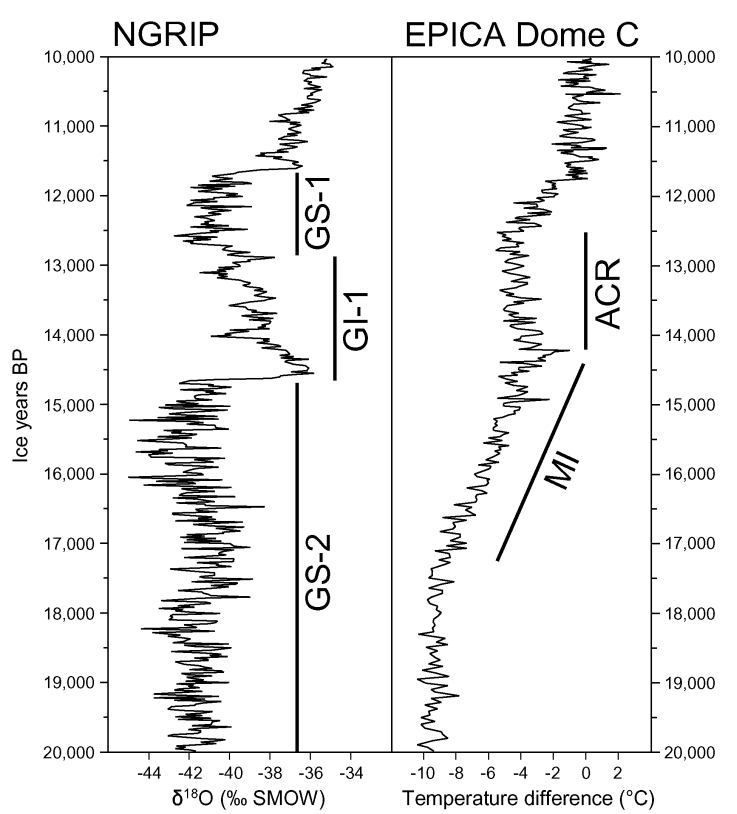

Figure 2 Comparison of the Greenland NGRIP oxygen isotope record (after Rasmussen et al., 2006 and Lowe et al., 2008) and the inferred temperature difference record from the Antarctic EPICA Dome C record (Jouzel et al., 2007). The Greenland Isotope events (GS-1, GI-1 and GS2) are clearly not coinciding with the Antarctic Cold Reversal (ACR) and Mystery Interval (MI).

in the north, but not in direct 'anti-phase' with the Bølling-Allerød (GI-1) warming in the north (Björck, 2006). While laminated lake sequences (Litt et al., 2001) confirm the synchroneity of the climate events during the LGIT in Europe, the ${ }^{14} \mathrm{C}$-dated laminated sequence from Lake Suigetsu in Japan (Nakagawa et al., 2003) points towards an offset in the Pacific region relative to both the Greenland and Antarctic ice- core records. Finally, in a recent paper, Firestone et al. (2007) presented new evidence for an extraterrestrial impact presumably causing the onset of the Younger Dryas. However, precise dating of the postulated impact is not very accurate and much more research is needed to confirm the occurrence of this event, and its possible impact on LGIT climate.

\section{Acknowledgements}

This is a contribution to the INTIMATE project of the INQUA Palaeoclimate Commission. Mike Walker is gratefully acknowledged for his valuable comments and correcting the language.

\section{References}

Alloway, B. V., Lowe, D. J., Barrell, D. J. A., Newnham, R. M., Almond, P. C., Augustinus, P. C., Bertler, N. A. N., Carter, L., Litchfield, N. J., McGlone, M. S., Vandergoes, M. J., Williams, P. W., and NZ-INTIMATE Members, 2007, Towards a climate event stratigraphy for New Zealand over the past 30,000 years (NZ-INTIMATE Project): Journal of Quaternary Science, 22, pp. 9-35.

Ammann, B., Birks, H. J. B., Brooks, S., Eicher, U., von Grafenstein, U., Hofmann, W., Lehmdahl, G., Schwander, J., Tobolski, K., and Wick, L., 2000, Quantification of biotic responses to rapid climatic changes around the Younger Dryas - a synthesis: Palaeogeography, Palaeoclimatology, Palaeoecology, 159, pp. 313-347.

Birks, H. H., and Ammann, B., 2000, Two terrestrial records of rapid climatic change during the glacial-Holocene transition $(14,000-9,000$ calendar years B.P.) from Europe: PNAS, 97-4, pp. 1390-1394.

Björck, S., Walker, M. J. C., Cwynar, L. C., Johnsen, S., Knudsen, K. -L., Lowe, J. J., Wohlfarth, B., and INTIMATE Members, 1998, An event stratigraphy for the Last Termination in the North Atlantic region based 
on the Greenland ice-core record: a proposal by the INTIMATE group: Journal of Quaternary Science, 13, pp. 283-292.

Björck, S., 2006, Younger Dryas oscillation, global evidence. In S. A. Elias, (Ed.): Encyclopedia of Quaternary Science, Volume 3, pp. 1987-1994. Elsevier B.V., Oxford.

Bond, G., Heinrich, H., Broecker, W., Labeyrie, L., McManus, J., Andrews, J., Huon, S., Jantschik, R., Clasen, S., Simet, C., Tedesco, K., Klas, M., Bonani, G., and Ivy, S., 1992, Evidence for massive discharges of icebergs into the North Atlantic ocean during the last glacial: Nature, 360, pp. 245-249.

Broecker, W. S., 1998, Paleocean circulation during the last deglaciation: a bipolar seesaw?: Paleoceanography, 13, pp. 119-121.

Coope, G. R., 1970, Climatic interpretation of Late Weichselian coleoptera from the British Isles. Revue de Géographie Physique et de Géologie Dynamique, 12, 149-155.

Coope, G. R., Morgan, A., and Osborne, P. J., 1971, Fossil coleoptera as indicators of climatic fluctuations during the Last Glaciation in Britain: Palaeogeography, Palaeoecology, Palaeoclimatology, 10, 87-101.

De Klerk, P., 2004, Confusing concepts in Lateglacial stratigraphy and chronology: origin, consequences, conclusions (with special emphasis on the type locality Bøllings $\emptyset$ ): Review of Palaeobotany and Palynology, 129(4), pp. 265-298.

Denton, G. H., Broecker, W. S., and Alley, R. B., 2006, The mystery interval 17.5 to 14.5 kyrs ago: PAGES Newslettter, 14(2), pp. 14-16.

Firbas, F., 1954, Die Synchronisierung der mitteleuropäischen Pollendiagramme: Danmarks Geologiske Unders øgelse II 80, pp. 12-21.

Firestone, R. B., West, A., Kennett, J. P., Becker, L., Bunch, T. E., Revay, Z. S., Schultz, H., Belgya, T., Kennett, D. J., Erlandson, J. M., Dickenson, O. J., Goodyear, A. C., Harris, R. S., Howard, G. A., Kloosterman, J. B., Lechler, P., Mayewski, P. A., Montgomery, J., Poreda, R., Darrah, T., Que Hee, S. S., Smith, A. R., Stich, A., Topping, W., Wittke, J. H., and Wolbach W.S., 2007, Evidence for an extraterrestrial impact 12,900 years ago that contributed to the megafaunal extinctions and the Younger Dryas cooling: PNAS, 104, pp. 16016-16021.

Grootes, P. M., Stuiver, M., White, J. W. C., Johnsen, S., and Jouzel, J., 1993, Comparison of oxygen isotope records from the GISP2 and GRIP Greenland ice cores: Nature, 366, pp. 552-554.

Hartz, N., and Milthers, V., 1901, Det senglaciale ler i Allerød Teglværksgrav: Meddelelser fra Dansk Geologisk Forening, 2, pp. 31-60.

Hoek, W.Z., 2001, Vegetation response to the $\sim 14.7$ and $\sim 11.5$ ka cal. BP climate transitions: is vegetation lagging climate?: Global and Planetary Change, 30, pp. 103-115.

Hughen, K., Lehman , S., Southon, J., Overpeck, J., Marchal, O., Herring, C., and Turnbull, J., 2004, 14C activity and global carbon cycle changes over the past 50,000 years: Science, 303, pp. 202-207.

Iversen, J., 1942, En pollenanalytisk Tidsfaestelse af Ferskvandslagene ved Nørre Lyngby: Meddelelser fra Dansk Geologisk Forening, 10, pp. $130-151$.

Jessen, K., 1935, The composition of the forests in Northern Europe in epipalaeolithic time: Biologiske Meddelser, 12(1), $64 \mathrm{pp}$.

Johnsen, S. J., Clausen, H. B., Dansgaard, W., Fuhrer, K., Gundestrup, N., Hammer, C. U., Iversen, P., Jouzel, J., Stauffer, B., and Steffensen, J. -P., 1992, Irregular glacial interstadials recorded in a new Greenland ice core: Nature, 359, pp. 311-313.

Jouzel, J., Masson-Delmotte, V., Cattani, O., Dreyfus, G., Falourd, S., Hoffmann, G., Minster, B., Nouet, J., Barnola, J.M., Chappellaz, J., Fischer, H., Gallet, J. C., Johnsen, S., Leuenberger, M., Loulergue, L., Luethi, D., Oerter, H., Parrenin, F., Raisbeck, G., Raynaud, D., Schilt, A., Schwander, J., Selmo, E., Souchez, R., Spahni, R., Stauffer, B., Steffensen, J. P., Stenni, B., Stocker, T. F., Tison, J. L., Werner, M., and Wolff, E. W., 2007, Orbital and Millennial Antarctic Climate Variability over the Past 800,000 Years: Science, 317, pp. 793-797.

Litt, T., Brauer, A., Goslar, T., Merkt, J., Balaga, K., Müller, H., RalskaJasiewiczowa, M., Stebich, M., and Negendank, J. F. W., 2001, Correlation and synchronisation of Lateglacial continental sequences in northern central Europe based on annually-laminated lacustrine sediments: Quaternary Science Reviews, 20, pp. 1233-1250.

Lotter, A. F., Eicher, U., Birks, H. J. B., and Siegenthaler, U., 1992, Lateglacial climatic oscillations as recorded in Swiss lake sediments: Journal of Quaternary Science, 7, pp. 187-204.

Lowe, J. J., Hoek, W. Z., and INTIMATE group, 2001, Inter-regional correlation of palaeoclimatic records for the Last Glacial-Interglacial Transition: a protocol for improved precision recommended by the INTIMATE project group: Quaternary Science Reviews, 20, pp. 1175-1187.

Lowe, J. J., Rasmussen, S. O., Björck, S., Hoek, W. Z., Steffensen, J. P., Walker, M. J. C., Yu, Z., and INTIMATE group, 2008, Precise dating and correlation of events in the North Atlantic region during the Last Termi- nation: a revised protocol recommended by the INTIMATE group: Quaternary Science Reviews, 27, in press, doi:10.1016/j.quascirev.2007.09.016.

Mangerud J., Andersen, S. T., Berglund, B. E., and Donner, J. J., 1974, Quaternary stratigraphy of Norden, a proposal for terminology and classification: Boreas, 3, pp. 109-128.

Nakagawa, T., Kitagawa, H., Yasuda, Y., Terasov, P. E., Nishida, K., Gotanda, K., Sawai, Y., and Yangtze River Civilisation Program Members 2003, Asynchronous climate changes in the North Atlantic and Japan during the Last termination: Science, 299, pp. 688-691.

Rasmussen, S. O., Andersen, K. K., Svensson, A. M., Steffensen, J. -P., Vinther, B., Clausen, H. B., Siggaard-Andersen, M. L., Johnsen, S. J., Larsen, L. B., Dahl-Jensen, D., Bigler, M., Röthlisberger, R., Fischer, H., Goto-Azuma, K., Hansson, M., and Ruth, U., 2006, A new Greenland ice core chronology for the last glacial termination: Journal of Geophysical Research, 111, D06102, doi:10.1029/2005JD006079.

Reimer, P. J., Baille, M. G. L., Bard, E., Bayliss, A., Warren, B. J., Chanda, B. J. H., Blackwell, P. G., Buck, C. E., Burr, G. S., Cutler, K. B., Damon, P. E., Edwards, R. L., Fairbanks, R. G., Friedrich, M., Guilderson, T. P., Hogg, A. G., Hughen, K. A., Kromer, B., McCormac, G., Manning, S., Ramsey, C. B., Reimer, R. W., Remmele, S., Southon, J. R., Stuiver, M., Talamo, S., Taylor, F. W., van der Plicht, J., and Weyhenmeyer, C. E., 2004, IntCal04 terrestrial radiocarbon age calibration, 0-26 cal kyr BP. Radiocarbon, 46, pp. 1029-1058.

Turney, C. S. M., Lowe, J. J., Davies, S. M., Hall, V., Lowe, D., Wastegård, S., Hoek, W. Z., Alloway, B., SCOTAV, and INTIMATE members, 2004, Tephrochronology of Last Termination sequences in Europe: a protocol for improved analytical precision and robust correlation procedures (a joint SCOTAV-INTIMATE proposal): Journal of Quaternary Science, 19, pp. 111-120.

Van der Hammen, T., 1949, De Allerød-oscillatie in Nederland, pollenanalytisch onderzoek van een laatglaciale meerafzetting in Drente, I \& II, Koninklijke Nederlandse Academie van Wetenschappen Proceedings, 52 , pp. 69-75 and 169-176.

Van der Hammen, T., 1951, Late-Glacial flora and periglacial phenomena in The Netherlands. PhD-thesis, Leiden, Leidse Geologische Mededelingen, 17, pp. 71-183.

Walker, M. J. C., Björck, S., Lowe, J. J., Cwynar, L. C., Johnsen, S. J., Knudsen, K. L., Wohlfarth, B., and INTIMATE Group, 1999, Isotopic 'events' in the GRIP ice core: a stratotype for the Late Pleistocene: Quaternary Science Reviews, 18, pp. 1143-1150.

Weaver, A. J., Saenko, O. A., Clark, P. U., and Mitrovica, J. X., 2003, Meltwater Pulse 1a from Antarctica as a Trigger of the Bølling-Allerød Warm Interval: Science, 299, 1709-1713.

Yu, Z., and Eicher, U., 1998, Abrupt Climate Oscillations During the Last Deglaciation in Central North America: Science, 282, pp. 2235-2238.

Wim Hoek is lecturer of Quaternary Geology and Geomorphology at the Department of Physical Geography, Utrecht University. He obtained his $\mathrm{PhD}$ on the Palaeogeography of Lateglacial Vegetations in 1997 at the Vrije Universiteit Amsterdam. His research is focused on the Late Weichselian and Early Holocene climate and associated environmental changes. He is co-ordinator of the INQUA Palaeoclimate Commission's North Atlantic INTIMATE project, which aims to synthesise ice-core, marine and terrestrial records that span the Last Termination (ca 22-11.5 ka cal BP). He is editor-in-chief of the Netherlands Journal of Geosciences, and serves on the editorial board of Quaternary Geochronology.

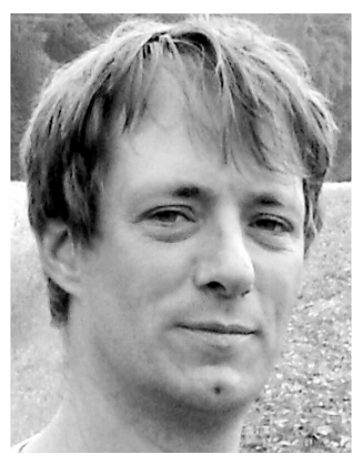

